\title{
Grassroots Democrats and the Japanese State After Fukushima
}

This article uses the case of the nuclear power industry post-Fukushima to lay bare how grassroots activism is disrupting the elite-driven model of Japanese democracy popularized in the developmental state literature. The experience of Japan's nuclear power industry after the 3/11 Triple Crisis-an earthquake, tsunami, and nuclear reactor disaster-attests to the diminished explanatory power of this elite-driven model of Japanese politics. Between the birth of the nuclear power industry and the 2011 disaster at the Fukushima Daiichi facility, Japan's political opportunity structures evolved to provide more people with more ways to challenge industry, bureaucrats, and politicians. Three years after the Fukushima disaster, all of Japan's nuclear reactors are offline. The inability of the nuclear power industry to resume business as usual attests to fundamental changes in state-society relations amid the dismantlement of the developmental state.

KEYWORDS: Fukushima, anti-nuclear movement, nuclear village, civil society, political participation

Sherry Martin MurPhY is a political scientist based in Washington, DC, whose research focuses on public opinion, political participation, and gender in Japan and the Asia-Pacific region. Prior to arriving in DC in 2011, where she is an employee of the U.S. Department of State, Dr. Murphy was an associate professor at Cornell University where she taught in the Government Department and the Program in Feminist, Gender, and Sexuality Studies. She is the author of Popular Democracy in Japan: How Gender and Community are Changing Modern Electoral Politics (Cornell, 2011) and coeditor of Democratic Reform in Japan: Assessing the Impact (Lynne Rienner, 2008). The views expressed in this article are those of the author, and do not necessarily reflect those of the U.S. Department of State or the U.S. Government. 


\section{Grassroots Democrats and the Japanese State After Fukushima}

THIS ARTICLE uses the case of the nuclear power industry post-Fukushima to lay bare how grassroots activism is disrupting the elite-driven model of Japanese democracy popularized in the developmental state literature. The developmental state model of Japanese politics (Johnson 1989; KInGsTON 2012) held that policies could be explained by examining the "iron triangles"-close-knit relationships among politicians, bureaucrats, and business interests-involved. Civil society was relatively weak and subordinate to the state. Elite actors used the resources available to them to build and maintain a public consensus around national growth and prosperity while intervening in the market to help new industries grow and old industries die.

The developmental state is very much alive in investigative and scholarly reporting on the role state and corporate interests played in the chain of events leading up to the March 11, 2011 "Triple Crisis"-an earthquake and tsunami which triggered a nuclear reactor disaster-and throughout the relief and recovery process. The experience of Japan's nuclear power industry after the 3/11 Triple Crisis, however, attests to the diminished explanatory power of this elite-driven model of Japanese politics. The developmental state's success in producing rapid economic growth and socio-demographic changes also produced fertile soil for grassroots political mobilization, and sowed the seeds for the growth of a stronger civil society and a democratic deepening of Japanese politics (PEKKANEN 2004).

This article relies on a rich and-in the aftermath of the 3/11 Triple Crisis-growing secondary literature on Japan's nuclear power industry, anti-nuclear movement reports, and public opinion polls by media outlets. I open with a review of the political science literature on the role of iron triangles in the growth of Japan's nuclear power industry, before turning to the experience of the anti-nuclear movement that grew up in its shadow. I then discuss how the position of the anti-nuclear movement became mainstream after the 3/11 Triple Crisis. Between the birth of the nuclear power industry and the March 2011 disaster at the Fukushima Daiichi facility, Japan's political opportunity structures-"specific configurations of resources, institutional arrangements and historical precedents for social mobilization, which facilitate the development of protest movements in some instances and constrain them in others" (KitsCHeLt 1986, 58)-had evolved to provide more people with more ways to challenge industry, bureaucrats, and politicians. Three years after the Fukushima disaster, all of Japan's nuclear reactors are offline. The inability of the nuclear power 
industry to resume business as usual attests to fundamental changes in state-society relations amid the dismantlement of the developmental state.

Japan's "Nuclear Village"

Even though many nuclear safety experts are still studying what went wrong at Fukushima, some voices inside Japan and internationally are questioning the role that human error and potential design flaws played in the nuclear disaster at the Fukushima facility following a massive earthquake and tsunami on March 11, 2011 (OsNos, 2011; BroINOwsKi 2012; DudDen 2012; Kingston 2012; Massey 2012; SAmuels 2013). Even so, more than a year after the crisis these same critics of Japan's nuclear administration predicted the industry would survive more or less intact. Below I describe the close ties that developed among politicians, bureaucrats, and business interests who collaborated to promote nuclear energy to support the nation's postwar economic development. This background is needed to fully appreciate how much the political terrain had shifted by $3 / 11$, and to pose questions about the likelihood that the post-3/11 restructuring of the industry will be merely cosmetic.

\section{JAPAN INC. GOES NUCLEAR}

Starting in the 1950s, the Japanese government along with peak business associations (e.g. Keidanren) began planning a nuclear future to make up for what the country lacked in natural resources and to reduce dependency on oil imports (HeIN 1990). Japan's Ministry of International Trade and Industry (MITI) used subsidies and other tools at its disposal to attract investors and lenders, and encouraged companies to enter the nuclear power industry. The Japan Development Bank subsidized loans for nuclear power development, providing utilities with a lower interest rate than commercial lenders (Cohen, McCubbins, and Rosenbluth 1994).

The Japanese government, led by the Liberal Democratic Party (LDP) through this period of nuclear expansion, played a leading role in finding locations and gaining public acceptance for nuclear power plants (ALDRICH 2008). In their case study of Kaminoseki, DusinberRE and ALDRICH (2011) detail what this small coastal town near Hiroshima that volunteered to host a nuclear power plant in the early 1980 s shared in common with other nuclear reactor sites. They were predominantly remote, coastal communities with declining populations and government deficits, and they lacked both the people and the resources to effectively launch a NIMBY (not-inmy-backyard) movement. This is not common to Japan and has been doc- 
umented cross-nationally in response to efforts to build not only nuclear power plants, but also oil and gas facilities (ANSOlabeHERE and KONISKY, 2009; Kitschelt 1986). While weak horizontal bonds made it difficult for residents to mobilize independently of the state, strong vertical bonds made it easy for pro-nuclear interests to lobby influential men who held leadership roles in overlapping local associations. Once utilities gained the support of local heads of chambers of commerce, fishing and farming cooperatives, and district and neighborhood associations, these opinion leaders were able to induce their rank-in-file to support the new plant. To ensure public acceptance, bureaucrats and companies poured in financial incentives-new jobs, infrastructure, and entertainment facilities-and used information campaigns and awards ceremonies for local elites. Once communities accepted nuclear power plants, they were unlikely to protest due to the benefits they reaped from resources that flowed into their communities (KInGSTON 2012; ALDRICH 2012a).

According to Cohen, McCubbins, and Rosenbluth (1994), "Japan's political, institutional structure allowed the LDP to ignore politically unimportant opponents of its policy" because "unitary government, parliamentarism, and majoritarianism combine(d) to allow for only one access point to government decision-making: the majority party (21-22)." Throughout the postwar period, the primary champions of the environmental and anti-nuclear movements among elite actors were the opposition parties (MCKeAN 1981). LDP politicians had little incentive to give voice to antinuclear interests because domestic industry-the nation's biggest energy consumers-provided a large share of the financing politicians needed to survive expensive campaign cycles (CoHEN et al. 1994). Moreover, politicians were able to subordinate broad public interests to those of the utility firms because most voters did not live in districts that hosted a nuclear power plant; they did not bear the direct risks of a nuclear accident, but they did enjoy the benefits of a stable energy supply (RAMSEYER 2012).

The industry's regulators-the Nuclear and Industrial Safety Agency (NISA) and Nuclear Safety Commission (NSC)-were housed under MITI, a condition that led some observers to question bureaucratic independence from the industry and their commitment to protecting the public interest (KINGSTON 2012). Bureaucrats might regulate in the interest of the firms because they were accountable to elected politicians who received campaign funding from utility firms (RAMSEYER 2012). The subordination of bureaucrats was a risk because LDP and party-affiliated politicians dominated every level of Japanese government (national, prefectural, and local), meaning that bureaucrats at every stage of the regulatory process- 
from financing, licensing, and siting to implementing and enforcing safety standards-fell under the control of the LDP (CoHEN et al. 1994, 17-18).

Residents who did mobilize against pro-nuclear interests used one of the few institutions available to voice grievances: the courts. However, the Japanese courts also had strong incentives to rule in favor of power companies over local communities and other anti-nuclear interests. The cabinet-elected officials-names the Supreme Court justices who supervise the judges in the court's personnel office, the Secretariat. "Secretariat judges monitor, evaluate, promote, and punish the rest of the court. By naming to the Supreme Court justices who share their policy preferences, the cabinet can ensure that lower court judges tend to adjudicate sensitive cases along ruling party policy lines" (RAMSEYER 2012, 481-82).

Contrary to local communities' oft-voiced complaints about the dangers nuclear facilities posed to public health, judges often found that the facilities were safe based on data and tests provided by researchers and the industry regulators. The regulators, however, depended on research conducted by nuclear experts in the private sector who received their funding from utilities and corporate interests whose businesses relied upon a stable and affordable energy supply (KINGSTON 2012). Experts with close ties to the industry drafted safety guidelines and the utilities determined whether they were compliant. Over time, utilities had incentives to downplay the regulatory agencies' warnings of safety risks and encouragement to adopt stricter international safety standards (RAMSEYER 2012).

The Japanese practice of amakudari- "the descent from heaven" whereby bureaucrats retire into positions in industries they previously regulated (e.g. the nuclear power industry) or enter politics where they are able to influence legislation that governs the policy arena they previously supervised (e.g. energy policy) - also served as the glue holding the three sides of the triangle together. The media, too, played a part; it was reliant on the financing energy companies provided through advertising (KINGSTON 2012).

\section{In the Shadow of the Nuclear Village: The Opponents Pre-3/11}

Others have written extensively about the genesis and evolution of Japan's anti-nuclear movement, specifically how it was shaped by the bombing of Nagasaki and Hiroshima in the Second world War, the 1954 Lucky Dragon No. 5 Incident (a Japanese tuna fishing boat was exposed to and contaminated by nuclear fallout from the thermonuclear device test on Bikini Atoll), and a broader environmental movement (Hook 1984). Below I focus on the political action repertoire that anti-nuclear activists built up 
over time. The ability of nuclear opponents to keep nuclear reactors offline today builds on a well-established arsenal of both conventional and unconventional tactics used by anti-nuclear activists from the 196os onward.

DAVID VS. GOLIATH?

Many communities that host nuclear reactors did not give up their sites without fighting alongside and within a broad-based anti-nuclear movement that grew up in the shadow of Japan's nuclear village (ALDRICH 2008; LEBLANC 2010). But in most accounts of confrontations between local host communities and the nuclear village, the victory went to the nuclear village. By the eve of $3 / 11$, nuclear interests had built enough reactors (54) to generate 30 percent of Japan's energy supply. Japan's nuclear power industry was a policy success story; policy planners were reaching their goals and had plans for future expansion. Further, the industry successfully and repeatedly defended itself against claims that reactors were unsafe (RAMSEYER 2012).

Anti-nuclear power opponents had their successes too. The nuclear power industry's success rate in siting plants was just over 50 percent; it successfully built 54 plants out of 95 attempts. In other words, the nuclear village failed nearly half of the time. And when it did succeed, the time between plant proposal and bringing it online increased from less than 10 years in the early 1970 s to over 30 years by the late 1990s, raising the costs for the industry (ALDRICH 2012a; RAMSEYER 2012). In the meantime, the nuclear opponents built and honed a political action arsenal in the local political arena.

\section{THE LOCAL ROOTS OF A NATIONAL MOVEMENT}

The beginnings of a national anti-nuclear movement were local, NIMBYstyle protests in communities where the first reactors were built in the mid1960 os and 1970s (ALDRICH 2008; NELSON 2011). Residents were concerned about the effects of the plants on public health, food safety, local fisheries and farming, and the local economy engaged in a range of conventional political actions. They took their battles to the courts, signed petitions, held local referendums, and fielded anti-nuclear candidates.

Local citizens opposed to building nuclear reactors in their backyards used the court system to sue, used land titles to prevent power companies from building, challenged the licensing process, and tried to legally block plants from going and staying online (RAMSEYER 2012, 467). Soon after the first reactor at the Fukushima Daiichi complex, the site of the 3/11 disaster, came online in 1971, local nuclear power opponents took their fight to the 
courts. They challenged Tokyo Electric Power Company's (TEPCO) landfill license to build a second (Daini) complex and contested the firm's operating license. They bought stock in the company and sued as shareholders. They filed an injunction to stop plans to modify a reactor at the Daiichi complex to use plutonium enriched mixed-oxide fuel (see CNIC [Citizens' Nuclear Information Center] newsletters from this period at http://www.cnic.jp/ english/newsletter/index.html). At each step the Fukushima litigants lost in a way that, according to RAMSEYER $(2012,469)$, typifies the experience of anti-nuclear cases: "Neighbors sue, claiming a threat to their health. They ask the court to shut down the reactor. Provided they live close enough, the courts grant them standing. They then dismiss on the merits: The reactors are safe." Even though local residents lost in court, their delaying tactics raised the power companies' operating costs and created a trove of documentation and evidence that could be retrieved at a later date.

Anti-nuclear interests achieved mixed results when they took the fight to the local election box (LeBlanC 2010; RAMSEYER 2012). In 1996, Makicho in Niigata prefecture became the first town in the postwar era where citizens initiated a referendum, and the issue at hand was whether or not their town should host a nuclear power plant (see KOBORI 2009 for a full account). Turnout was high (88.2 percent) and a majority of voters (61 percent) rejected the nuclear power plant. Plans to build the reactor died when the mayor sold the planned site for the facility to anti-nuclear campaigners. Despite the high costs and risks of referendum campaigns to citizens - after collecting the signatures of $1 / 50$ th of residents, local assemblies can deny their request to hold a referendum, or grant the request and ignore the results since they are non-binding-17 more referendums were held prior to the $3 / 11$ crisis and nuclear power was at the heart of two (KoBORI 2009; VOSSE 2004; BURGESS 2013). Turnout in both of the other anti-nuclear referendums (and referendums in general) was exceedingly high when compared to turnout for national elections, signaling the potential for high levels of citizen interest in and engagement with these issues even beyond the local context. However, earlier referendums focused on the local issue of whether or not to build nuclear reactors in their backyards and did not promote a broader national political debate on the merits of the national dependency on nuclear power generation (VOSSE 2004) that we are seeing today.

Even when local residents failed to block nuclear power plants, they succeeded in mobilizing resources and building networks and organizations that helped the movement to grow and fight another day. The national movement emerged when groups such as the Citizen's Center for Nuclear 
Information (CNIC), founded in 1973, began to link local anti-nuclear groups to one another to enable them to share information and strategies for postponing or preventing the construction of nuclear power plants (NeLson 2011). The CNIC's newsletter, with nearly three decades worth of issues now available online in Japanese and English, is one mechanism this organization used to knit together a broad-based movement out of grassroots activism in small towns that were considered part of Japan's dying hinterlands. The bimonthly newsletter explains nuclear technology, energy policy, and citizens' rights in layman's terms in an effort to expand and open up the debate to everyday people locally, nationally, and globally. A typical issue includes articles on: technological advances in nuclear energy; plant design and safety issues; susceptibility of reactors to natural disasters; the status of the nuclear power industry in other countries; cost/benefit analyses of nuclear energy; and radiation exposure of nuclear power plant workers. The newsletter also served as a networking vehicle; its spotlight on individual activists and local organizations helped to recruit new members while putting like-minded interests into contact with one another.

\section{Japan's Nuclear Power Industry: A Phoenix Rising from the Ashes?}

In the year following the Fukushima crisis, many predicted the antinuclear movement would gain little traction (OsNOS 2011; ALDRICH 2012b). Nationally, Japanese were economically dependent upon a stable energy supply, and local communities with reactors were economically dependent on the revenues and jobs the facilities generated (ALDRICH 2012b). Not only were anti-nuke demonstrations judged to be "moderate" with "few signs of a broad-based, sustained anger or opposition to nuclear power," they had little effect on public opinion in the immediate aftermath of the accident (AlDRICH 2012b, 133). National opinion polls in spring 2011 showed "some negative movement among individuals who may have been neutral on the issue before the accident, but overall the main trend remains mixed feelings on the issue" (ALDRICH 2012b, 133). Further, even some environmentalists saw nuclear power as unavoidable if Japan was to reduce consumption of fossil fuels to counteract global warming (OsNos 2011).

As investigations into the nuclear accident raised questions about competence, the Japanese public lost all confidence in the industry and official regulators, resulting in a shutdown of all of the nation's nuclear reactors by mid-2013. The institutional changes required to demonstrate the nuclear power industry's integrity, high safety standards, and commitment to the public interest held the potential to unravel the industry altogether by rais- 
ing operating costs and providing more opportunities for nuclear opponents to resist. The "iron triangle" comprising the postwar nuclear power energy is being reorganized. The government ordered the nation's reactors to submit to stress tests that simulated natural disasters in an effort to guarantee the safety of any reactors that are brought back online. It also nationalized TEPCO, which could not pay the high costs of clean-up and recovery; it split the agencies that promote nuclear energy from those that regulate the industry, and created new ones; and passed a tariff to promote use of renewable energy sources. Media outlets are reporting on an increase in foreign firms investing in Japan's renewable energy market and Japanese government support for building geothermal power plants. If more alternative energy sources come online in the near future, it may become more difficult for utilities to gain public support for restarting existing nuclear reactors.

Despite these developments, there is evidence that the nuclear power industry remains intact. When the Japanese government nationalized TEPCO to prevent it from collapsing, it settled for only 50.1 percent voting shares instead of the 75 percent it was entitled to, an amount that would have given it enough control for a complete reorganization (KINGSTON 2012). The ruling LDP continues to advocate reactor restarts, and business interests are calling for continued reliance on nuclear energy. Moreover, "the export of nuclear power plants was reaffirmed as a matter of national policy, and the institutions of the much-disputed 'back end' of the nuclear fuel cycle-the Mutsu fast breeder reactor and the Rokkasho-mura reprocessing facility-remained largely intact despite dwindling public support" (SAMUELS 2013, 118).

Whether institutional changes dismantle the nuclear village or it rebounds more or less unchanged, utility companies still face high and growing barriers to bringing existing reactors back online-much less building new ones-as long as TEPCO remains unable to contain the last disaster. Toxic water is still leaking into the groundwater and ocean surrounding the Fukushima Daiichi facility. Media attention to ongoing crisis management and the plight of evacuees from the exclusion zone is a constant public reminder of the risks and costs associated with nuclear energy.

The industry has not been able to win back the support of many local communities that host nuclear facilities or Japanese nationwide. Half of the Japanese public still supported nuclear power generation a month after 3/11, according to Asahi Shimbun polls. By May 2011, more Japanese opposed nuclear power generation than supported it. In summer 2012, the Japanese government commissioned a deliberative poll to explore public preferences for one of three policy options: phase out nuclear energy alto- 
gether (the zero percent option) by 2030; reduce the nation's reliance on nuclear power to 15 percent of total energy supply; or reduce reliance to 20-25 percent of total supply (http://cdd.stanford.edu/polls/japan/). Over the course of two days, deliberative polling participants received printed materials to increase their knowledge of energy use at home and abroad and its economic impact, attended question-and-answer sessions with experts, and discussed policy options in groups. As participants learned more about nuclear power, they became more opposed to a future that includes nuclear energy. Safety became even more important and support for the zero option increased over the deliberative process.

Nationwide most Japanese continue to distrust new and existing safety measures, and public opposition to nuclear power has remained stable over time; the majority oppose restarting the reactors. Even those who support restarting existing reactors agree that Japan should phase out nuclear power altogether in the future. By late 2013, three-quarters (72 percent) of Japanese said they supported phasing out the nation's nuclear power generation (Asahi Shimbun, November 12, 2013). In the meantime, TEPCO is decommissioning all of the reactors at the Fukushima Daiichi facility while it and other utility companies are lobbying to restart some reactors in summer 2014 and 2015.

\section{Citizens Storm the Castle: Grassroots Activists Respond to 3/11}

The political landscape that the nuclear power industry faces today differs significantly from Japan Inc.'s initial forays into nuclear energy. Citizens have relatively more power and iron triangles have somewhat less. Japan's political opportunity structures-its institutional arrangement and distribution of resources that facilitate political engagement-shifted in the intervening years to strengthen the anti-nuclear movement relative to the nuclear village. KITSCHELT argued that social movements' access to the public sphere and political decision-making, and their success in reaching their goals, is contingent upon institutional rules that govern patterns of interaction between government and interest groups $(1986,61)$.

New technologies have dramatically changed the configuration of informational resources available to anti-nuclear activists by expanding the amount of information they can collect, generate, and analyze; increasing the number and reach of dissemination channels; and by increasing their capacity to mobilize supporters. On the institutional front, administrative decentralization is one example of many rule changes that have given rise to new patterns of interaction between government and citizens in Japan. 
Decentralization has created new incentives and opportunities for citizen activism at the grassroots level while also altering voters' decision-making processes in local and national elections by breaking the electoral connection between different levels of government (SAITO and YAMADA 2011).

THE MOVEMENT BROADENS

Anti-nuclear protestors are using new technologies to expand the movement's base and reach (SLATER 2011). While back issues of CNIC newsletters show lengthy experience with citizen science-local residents measuring local radiation levels and monitoring their food supply-distrust in officials has led to crowdsourcing with citizens, creating their own radiationmeasuring devices to track and upload radiation levels across the country to an open source web-based platform. SAFECAST makes radiation readings across Japan internationally available (http://blog.safecast.org) and its data rivals-some say surpasses-the quantity and quality of information issued by government and industry. Constant broadcasts that contradict government reports on the threat the Fukushima accident continues to pose to public safety is an effective mobilizing device.

Six months after the disaster, a group called "1o Million People's Action to Say Goodbye to Nuclear Power Plants" and headed by public intellectuals mobilized 60,000 people from all over the country to rally in Tokyo's Meiji Park. The rally was three times the size of the 1988 record-breaking anti-nuke demonstration after the Chernobyl disaster and one of the largest the nation has witnessed since the mass protests against the U.S.-Japan Security Treaty in the late 1960s. Outside of a few large-scale demonstrations, anti-nuclear rallies outside of the prime minister's residence have become a routine occurrence.

Millions have signed anti-nuclear petitions, and signature campaigns were crucial to the efforts of civil society groups such as Minna de Kimeyo Genpatsu Kokumin Tōyō in launching referendum campaigns in Osaka, Tokyo, Shizuoka, and Niigata. In all cases citizens collected more than the required number of valid signatures to initiate a vote on ordinance bills calling for local referendums on the future of nuclear energy, and the municipal assemblies voted the bills down every time. Even so, many would call these efforts successful in issuing a credible threat; politicians are on guard that if there is enough opposition for a successful signature campaign, there is also enough opposition to threaten their seats at election time. There are signs that Osaka mayor and founder of the Japan Restoration Party Toru Hashimoto is suffering for not firmly adhering to his initial calls for ending nuclear power. He deemed a potential Osaka refer- 
endum an unnecessary and costly measure in light of the fact that he had already begun preparing a shareholders' proposal to submit to the regional utility company, and argued that his own election victory demonstrated citizen's will to reduce dependency on nuclear energy. A few short months later, his party moderated its stance in national elections. It now appears that his ambitions for national office are not being met with the same level of public enthusiasm that greeted his initial forays into the political arena.

TAKING ON NAGATACHO:

THE ANTI-NUCLEAR MOVEMENT AND NATIONAL ELECTIONS

Decentralization and demographic changes at the grassroots level have upended the LDP's support bases in districts nationwide, especially its rural strongholds. At the height of Japan's developmental state, clientelism and fiscal centralization in a unitary system sustained LDP dominance, especially in rural districts with smaller independent tax bases (SCHEINER 2006). Local politicians relied on the central government to funnel goods and services to their districts, and those most successful at bringing home the pork had a higher likelihood of reelection by voters who wanted to keep resources flowing into their districts. For their part, local politicians mobilized their districts to turn out for LDP candidates in prefectural and national elections.

The Law to Promote Decentralization (1995) triggered municipal mergers to help depopulated areas to realize economies of scale necessary to shoulder a heavier administrative burden and, in doing so, disrupted local electoral districts and the traditional social networks that politicians relied on for reelection. Politicians at lower levels of government are less beholden to the national party and have greater incentives to promote constituents' interests. These changes have provided opportunities for outsider perspectivesthrough parties, candidates, and voters - to gain a foothold in different levels of Japanese government. Anti-nuclear activists are currently influencing every level of Japanese politics, forcing the ruling LDP to moderate its energy policy nationally while chipping away at the nuclear village at the local level.

When the December 2012 House of Representatives Election swept the pro-nuclear LDP back into power, many followers of Japan's anti-nuclear movement bemoaned the party's victory as further evidence of the antinuclear movement's limitations. However, the very fact that the movement broke the surface of national politics speaks to its success. Even though multiple public opinion polls showed that a majority of Japanese said that the economy and social security were deciding factors when they cast their votes, the primacy of these issues did not mean that voters were willing to abandon their anti-nuclear stance. According to a December 2012 Jiji Press 
poll conducted prior to the election, 85 percent of Japanese nationwide said they worried that an earthquake and tsunami will trigger a nuclear accident. In the three weeks preceding the election, 1.12 million Twitter messages (37 percent of the total) mentioned nuclear power (The Japan Times, December 12, 2012), making it the most tweeted campaign issue. Nuclear power tweets topped comments about the economy and foreign policy, respectively the second and third most tweeted issues.

The anti-nuclear movement, with the strength of public opinion behind it, influenced candidates' campaign behavior by constraining the limits of viable positions they could take on the future course of the nation's energy policy. The pro-nuclear LDP's victory was a landslide, reflecting voters' faith that the party represents the nation's best chance for turning around the economy. Even so, the LDP did not advocate immediately restarting idle reactors; the party promised to make a decision on restarting them within three years and to determine the best mix of energy sources for the nation within a decade. The party placing second, the newly-formed Japan Restoration Party, moderated its anti-nuclear stance; they embraced a gradual reduction in the nation's reliance on nuclear energy over time in order to avoid the negative economic repercussions of immediate elimination. While explicitly anti-nuclear candidates and parties were largely unsuccessful, successful candidates and parties were reluctant to take a staunchly pro-nuclear stance and unequivocally advocate for a wholesale restart of nuclear power plants nationwide.

The weak showing of anti-nuclear candidates and parties in the election speaks more to the structural and organizational problems these small parties confronted rather than to the unpopularity of their message. Supporters of the Tomorrow Party of Japan and Your Party were more concerned about the likelihood of another nuclear accident in the future than voters who threw their support behind other parties. But, most voters did not have the opportunity to vote for anti-nuclear candidates; these smaller parties ran fewer candidates in districts across the nation. The Tomorrow Party of Japan was established less than three weeks before the election and its candidates-half of whom were political newcomers-did not have the time to establish name recognition with the public. As discussed below, nuclear opponents have continued to pursue their agenda at the local level where there are more opportunities to influence the course of energy policy.

The LDP victory was not the victory for the nuclear power industry that business elites, media commentators, and many Japan watchers abroad predicted. Even since the LDP's decisive victory in the Upper House election in July 2013 solidified its control over both houses of the Diet, the Abe 
administration has not brought any reactors back online. With time, more politicians within the LDP are changing their positions on the role of nuclear power in Japan's energy supply, now and in the future. Ex-premier Junichiro Koizumi, a former nuclear power proponent, announced in November 2013 that it was irresponsible to continue nuclear power generation when there are no prospects of locating a nuclear waste disposal site. Further, it was crucial that the government gained the consent of local residents given that taxpayer money is spent on plant construction. Money would be better spent developing natural energy resources (DEWIT 2013).

A month after Koizumi's high profile change of heart, the weekly Shukan Gendai reported ("LDP lawmakers split over nuclear power generation"; December 7, 2013, 41-44) that the ruling LDP was divided over nuclear power generation. Both groups of lawmakers-those in favor of nuclear power and those against-include party heavyweights, but the nuclear opponents are younger on average and still moving up within the ranks of the party. As public opposition to nuclear power has broadened and deepened since $3 / 11$, younger politicians may believe their position on energy policy could be a determining factor in their political futures. Further, their shorter tenure in government means they have not had the time to build up the ties with business and bureaucrats that make senior politicians more beholden to the nuclear energy lobby. The anti-nuclear position may become mainstream in elite politics with generational change among conservative politicians.

Anti-nuclear activists might not have to wait for generational change in the upper echelons of government to achieve measurable gains. The national government publicly committed itself to not restarting nuclear reactor restarts without the permission of local municipalities, requiring the nuclear village to win over local communities one by one. Anti-nuclear activists have lost some high-stakes, low-frequency, battles: the national election in 2012 and the February 2014 Tokyo gubernatorial election, both widely framed as referendums on nuclear energy. However, they still have a multitude of chances to win the war: nearly one-third of local governments have submitted statements to the national government calling for ending reliance on nuclear energy.

Political observers framed the outcome of Tokyo's gubernatorial election as a bellwether-it would serve as an indicator of what to expect to see replayed in local elections across the country. The anti-nuclear movement stood to achieve a major victory when former Prime Minister Hosokawa entered the race with Koizumi's support, campaigning on the promise of zero nuclear power. When the win instead went to the pro-nuclear, LDP- 
backed Yoichi Masuzoe, it cast doubts on the size and strength of the antinuclear vote. However, those who predicted-based on Masuzoe's victory and sizable lead over Hosokawa, who placed third-that Prime Minister Abe would have the leeway to restart some nuclear reactors as early as summer 2014 may be jumping the gun.

Tokyo voters did in fact voice their support for two anti-nuclear candidates. Some analysts argue that Masuzoe owes his victory to the fact that the anti-nuclear vote was split and that the weather-snow on the eve of the election-contributed to low voter turnout. Socialist lawyer and anti-nuclear candidate Kenji Ustunomiya placed second in the race. When the votes won by both anti-nuclear candidates are combined, Masuzoe's margin of victory shrinks substantially. Moreover, the LDP tends to benefit from low turnout. A January 2014 LDP-sponsored election simulation predicted that if turnout were 55 percent more independents and opposition supporters would have come to the polls to deliver Hosokawa a victory (http://www.news-postseven.com/archives/20140120_237066.html [accessed February 14, 2014]).

A recent Asahi Shimbun study ${ }^{1}$ predicts a rocky road ahead for those who want to restart nuclear power plants. Since 2011, nearly one-third of local governments nationwide ( 455 of 1788) have submitted statements to Tokyo that call for eliminating nuclear energy from Japan's energy portfolio. The Local Autonomy Law empowers individual local assemblies to adopt and submit to the national Diet a statement on an issue for the purpose of having local opinion reflected in national policy. While the national government is not legally required to reflect these opinions in the policymaking process, the initiative shown by local governments speaks volumes about the scope of opposition nuclear proponents are likely to face moving forward.

\section{Governance, Activism, and Japan's Energy Future}

Despite the criticism heaped on Japan's nuclear village immediately after $3 / 11$, one observer urges us not to dismiss the fact that Japanese democracy worked: "[T]he fundamentals of Japan's open society served it well in the aftermath: elected officials ordered evacuations ... parliament launched investigations into all that went wrong; and the Japanese press chronicled a raging national debate about the future" (OsNos 2011). As the nation's most dire nuclear event to date, the $3 / 11$ disaster at the Fukushima facil-

1. See http://ajw.asahi.com/article/views/vox/AJ201401210025 (accessed February 21, 2014) and http://ajw.asahi.com/article/o311disaster/fukushima/AJ201401190021 (accessed February 21, 2014) 
ity was bound to capture public attention. Still, the magnitude of activism and the strength of sustained opposition to nuclear restarts that we see today was not a forgone conclusion. Prior nuclear accidents failed to produce the current level of civil society engagement on this issue and the nuclear power industry emerged relatively unscathed. In this article, I have argued that Japanese state-society relations have undergone a significant transformation in the time between the birth of the nation's nuclear power industry and today. The events after $3 / 11$ illustrate the breakdown of the developmental state, a model of state-society relations that held significant explanatory power in interpreting Japanese politics from 1955 through the 198 os, including the constraints past anti-nuclear activists faced in holding the nuclear village accountable.

The developmental state literature subordinates a weak civil society to the iron triangle of politicians, bureaucrats, and business elites. State-society relations, however, are not static and the interaction between Japan's anti-nuclear movement and nuclear industry stakeholders illustrates how the balance of power has shifted as a result of changes in the nation's political opportunity structure. Anti-nuclear activists had decades of experience prior to the $3 / 11$ disaster. They amassed an archive documenting how elites subordinated the public interest to the nuclear village, fought the industry in courts, and overcame institutional barriers to initiate local referendums. Technological advances and the information revolution provided the movement with the resources it needed to extend its reach nationally and globally. During this time, Japan's political opportunity structure also experienced significant changes; administrative decentralization was one that fundamentally upset the sociopolitical balance that sustained the iron triangle mentioned above who made up Japan's nuclear village. The Triple Crisis was the catalyst that brought the nuclear village and the anti-nuclear movement together in a head-to-head struggle that lays bare the transformations that the Japanese state and society have experienced.

Post-3/11 anti-nuclear activism attests to growing civil society and participatory democracy at the grassroots, and the dismantlement of Japan's development state. Anti-nuclear opponents are not just taking to the streets; they are mobilizing public opinion to make their way into institutionalized arenas of decision-making. Japan's energy future remains insecure, but this unfolding drama in state-society relations provides numerous opportunities for ongoing and future research. The disjuncture between the conventional wisdom and events unfolding on the ground offer opportunities for political scientists to think about how Japanese state and society can partner to rebuild democracy better. 


\section{REFERENCES}

AldRICH, Daniel

2013 "A Normal Accident or a Sea-Change? Nuclear Host Communities Respond to the 3/11 Disaster." The Japanese Journal of Political Science 14 (2): 261-76.

2012a "Post-Crisis Japanese Nuclear Policy: From Top-Down Directives to Bottom-Up Activism.” Asia Pacific Issues 103: 1-11.

2012b "Networks of Power: Institutions and Local Residents in post-Tohoku Japan." In Natural Disaster and Nuclear Crisis in Japan, ed. Jeff Kingston, 127-39. London and New York: Routledge.

2008 Site Fights: Divisive Facilities and Civil Society in Japan and the West. Ithaca, NY: Cornell University Press.

Ansolabehere, Stephen, and David M. Konisky

2009 "Public Attitudes Toward Construction of New Power Plants." Public Opinion Quarterly 73: 566-77.

Bestor, Theodore C.

2013 "Disasters, Natural and Unnatural: Reflections on March 11, 2011, and Its Aftermath." The Journal of Asian Studies 72: 763-82.

BRoINOWSKI, Richard P.

2012 Fallout from Fukushima. Victoria, Australia: Scribe Publications Pty Ltd.

Burgess, Chris

2013 "Democracy Interrupted: How Local Voices Were Silenced in Tokyo's First Referendum.” http://www.japantimes.co.jp/community/2013/o6/18/issues/democracy-interrupted-how-local-voiceswere-silenced-in-tokyos-first-referendum/\#.Uyk50KiSw40 (accessed February 21, 2014).

Cohen, Linda, Matthew McCubbins, and Frances Rosenbluth

1994 “The Politics of Nuclear Power in Japan and the United States." http:// mccubbins.us/mccubbins_files/ARTB11.PDF (accessed April 23, 2014).

Dalton, Russell J., Steve Reccia, and Robert Rohrschneider

2003 "The Environmental Movement and Modes of Political Action." Comparative Political Studies 20: 1-29.

DeWit, Andrew

2013 "Just Gas? Smart Power and Koizumi's Anti-Nuclear Challenge." The Asia-Pacific Journal: Japan Focus 11 (50.3). http://japanfocus.org/Andrew-DeWit/4049 (accessed March 3, 2014).

DudDen, Alexis

2012 “The Ongoing Disaster." The Journal of Asian Studies 71: 345-59. 
Dusineberre, Martin, and Daniel P. Aldrich

2011 "Hatoko Comes Home: Civil Society and Nuclear Power in Japan." The Journal of Asian Studies 70: 683-705.

HeIN, Laura

1990 Fueling Growth: The Energy Revolution and Economic Policy in Postwar Japan. Cambridge, MA: Harvard University Press.

Hook, Glenn D.

1984 "The Nuclearization of Language: Nuclear Allergy as Political Metaphor." Journal of Peace Research 21: 259-75.

Horiuchi, Yusaku

2005 Institutions, Incentives and Electoral Participation in Japan: Cross-Level and Cross-National Perspectives. New York: RoutledgeCurzon.

Kingston, Jeff

2012 "Japan's Nuclear Village." The Asia-Pacific Journal: Japan Focus 10 (37.1). http://www.japanfocus.org/-Jeff-Kingston/3822 (accessed December 20, 2013).

Kitschelt, Herbert

1986 "Political Opportunity Structures and Political Protest: Anti-Nuclear Movements in Four Democracies." British Journal of Political Science 16: 57-85.

KовоRI, Mashiro

2009 "Referendums in Britain and Japan: Turnouts, Campaigns, and Systems." Ritsumeikan Law Review 26: 1-25.

LeBlanc, Robin M.

2010 The Art of the Gut: Manhood, Power, and Ethics in Japanese Politics. Berkeley, CA: University of California Press.

MAsser, Nathanael

2012 "Report Blames Fukushima Disaster on Top Levels of Utilities, Regulators." ClimateWire. http://www.eenews.net/special_reports/nuclear_ crisis (accessed July 9, 2012).

McKeAn, Margaret

1981 Environmental Protest and Citizen Politics in Japan. Berkeley, CA: University of California Press.

Nelson, Craig

2011 "The Energy of a Bright Tomorrow: The Rise of Nuclear Power in Japan.” Origins: Current Events in Historical Perspective 4(9). http:// origins.osu.edu/article/energy-bright-tomorrow-rise-nuclear-powerjapan (accessed January 2, 2014).

OsNos, Evan

2011 "Letter from Fukushima: The Fallout." The New Yorker. http://www.new- 
yorker.com/reporting/2011/10/17/111017fa_fact_osnos?currentPage=all (accessed April 23, 2014).

PEKKANEN, Robert

2004 "After the Developmental State: Civil Society in Japan." Journal of East Asian Studies 4: 363-88.

RAMSEYER, J. Mark

2012 "Why Power Companies Build Nuclear Reactors on Fault Lines: The Case of Japan." Theoretical Inquiries in Law 13: 457-85.

SAITo, Jun, and Kyohei Yamada

2011 “Local Government in Japan." In The Routledge Handbook of Japanese Politics, ed. Alisa Gaunder, 103-14. London and New York: Routledge.

SAMUELS, Richard J.

2013 “Japan's Rhetoric of Crisis: Prospects for Change after 3.11." The Journal of Japanese Studies 39: 97-120.

SCHEINER, Ethan

2006 Democracy Without Opposition in Japan. Cambridge: Cambridge University Press.

Slater, David H.

2011 "Fukushima Women Against Nuclear Power: Finding a Voice From Tohoku." The Asia-Pacific Journal. http://www.japanfocus.org/events /view/117 (accessed February 6, 2013).

Steel, Gill, and Sherry L. Martin

2008 "Introduction." In Democratic Reform in Japan: Assessing the Impact, Sherry L. Martin and Gill Steel, eds., 1-8. Boulder, CO: Lynne Rienner Publishers.

TAKAO, Yasuo

1998 “Participatory Democracy in Japan's Decentralization Drive." Asian Survey 38: $950-67$.

TANAKA, Yutaka

2004 "Major Psychological Factors Determining Public Acceptance of the Siting of Nuclear Facilities." Journal of Applied Social Psychology 34: $1147-65$.

Vosse, Wilhelm

2004 "Civil Society in Times of Depolitization." In Japan in the 1990s: Crisis as an Impetus for Change, ed. Gesine Foljanty-Jost, 153-78. Berlin, Vienna, London: Lit Verlag. 